\title{
Post shared, vote shared. Investigating the link between Facebook performance and electoral success during the Hungarian general election campaign of 2014
}

Abstract

This study investigates how candidates' Facebook performance, measured by the number of average shares, likes and comments per post, affects the personal vote they gained during the Hungarian general election campaign of 2014. The database contains three of the most votedfor candidates owning Facebook pages from all single-member districts. The results show that the average number of shares on candidates' Facebook pages is positively associated with electoral outcome after controlling for, inter alia, the vote share of their respective party on list in the districts, while the numbers of likes and comments are not significantly related to the dependent variable.

Keywords: Virality, personal vote, campaign effect, Facebook

While public discourse abounds with interpretations and anecdotal evidence regarding the role social media campaigns play in electoral successes, few empirical efforts have been made to clarify whether and to what extent electoral performance is shaped by the use of information and communication technology (ICT) campaign tools in general, and social media in particular. Furthermore, the limited amount of existing research has primarily focused on the effects of the adoption of campaign websites (e.g. D’Alessio, 1997; Gibson \& McAllister, 2006; Sudulich \& Wall, 2010; Koc-Michalska et al, 2014) and Twitter (e.g. Kruikemeier, 2014). However, as digital campaign tools are increasingly commodified in election campaigns (see Vaccari, 2010; Bimber, 2014), the way they are used is becoming more of a crucial question than their mere adoption. This research moves beyond the issue of adoption, and attempts to connect Facebook performance with electoral performance. It assumes that Facebook campaigning results in extra votes through a two-step flow effect (see Gibson \& McAllister, 2015): the shares of candidates' posts generate extra votes because this 
way messages through the mediation of candidates' followers can reach voters who would otherwise not see that content. Therefore, the present study focuses on the relationship between the number of average shares of candidates' posts and the personal vote they gained, controlling for several candidate-level variables. A unique dataset containing 184 major party single-member district (SMD) candidates owning Facebook pages during the Hungarian general election campaign of 2014 is applied to test hypotheses. To justify that indeed the predicted relationship took place through a two-step flow mechanism, the effects of other performance variables, such as the numbers of average likes and comments, which are connected to virality to a lesser degree, are also examined.

The Hungarian case is especially suited to testing these hypotheses as the partycentred political system (Papp, 2014), the high level of partisanship (Patkós, 2017) and the low level of electoral volatility (Powell \& Tucker, 2014) make it a least likely case of the predicted effect. Furthermore, the mixed member electoral system enables us to capture personal votes in inter-party competition more precisely than previous research in other electoral contexts could. The findings support the hypotheses: the number of average shares of candidates' Facebook posts is moderately but significantly and positively associated with candidates' vote share after controlling for, inter alia, the vote share of their respective party on list within their respective SMDs. In addition, the numbers of likes and comments did not have a significant effect on the dependent variable, a result that yields a strong argument for the two-step flow hypothesis of the social media campaign effect.

In the first section, I trace the theoretical background, which is followed by a detailed discussion of the Hungarian case. Next, methods and findings are presented, and the article is finished with some concluding remarks.

\section{Theoretical Background}




\section{The Information and Communication Technology (ICT) Campaign Tools and the Two-}

\section{Step Flow Effect}

The first empirical research on the effect of ICT campaign tools was published as early as 1997 about the 1996 US Presidential and Congressional Election, which was the very first US election extensively using the World Wide Web (D'Alessio, 1997). Despite this early start, subsequently little research has been conducted in the field: only a few case studies have empirically investigated the effect of web campaigning (Gibson, 2012). These works have primarily focused on the effects of the adoption of campaign web sites on candidates' electoral performance. Interestingly, the small number of studies conducted in very different electoral and political contexts has usually found small but significant effects (D'Alessio, 1997; Gibson \& McAllister, 2006; Sudulich \& Wall, 2010; Koc-Michalska et al, 2014, but as an exception, see Rackaway, 2007). The consistency of empirical findings was rather surprising as this result was in sharp contrast with studies that used survey methods for investigating the effects of visiting campaign web sites on voters' political behavior. Those works demonstrate that only a small minority of voters visit campaign sites and this has no effect whatsoever on their voting intentions (Bimber \& Davis, 2003; Park \& Perry, 2008). Even less attention has been devoted to the effects of social media use on electoral performance, moreover the few works we have concentrate mostly on Twitter (Spierings \& Jacobs, 2014; Kruikemeier, 2014; Jacobs \& Spierings, 2016a; Sobaci et al, 2016) or some aggregated measures of web 2.0 campaign tools (Gibson \& McAllister, 2011, 2015; Effing et al, 2016) rather than the most popular social media site, Facebook. Nonetheless, the research on electoral effects has given more mixed results for adopting social media than for web sites. While some work has demonstrated small, but significant positive effects (Kruikemeier, 2014; Sobaci et al, 2016), in the Australian context, only in the case of the Green candidates was a positive significant relationship identified (Gibson \& McAllister, 2011, 2015). 
Conflicting evidence between electoral performance and voter survey research has encouraged scholars to find explanations for these results. Of the several competing assumptions (see D’Alessio, 1997: 20; Jacobs \& Spierings, 2016b: 161-163), the most elegant solution is offered by the two-step flow hypothesis: it is not the direct visitors or followers who are affected by website or social media content, but their friends and acquaintances (Sudulich \& Wall, 2010; Gibson \& McAllister, 2015). The two-step flow hypothesis was originally formulated to explain the effects of mass media on the wider population (see Lazarsfeld et al, 1948), but its logic seems to be adoptable to politicians' campaign communication. The visitors and followers convey information and arguments obtained from websites or social media pages to their friends, who are thus indirectly influenced by their content. This hypothesized mechanism would reconcile the findings of electoral performance studies and voter survey research.

Electoral performance research has not yet empirically tested this hypothesis, but findings from related fields may offer some support for it. First, there are signs that voters who visit political actors' webpages or follow them on social media sites constitute a special segment of the voter population. Bimber and Davis (2003), for example, found that they are typically knowledgeable, politically interested and committed to the candidates. However, subsequent research added further aspects in which this audience differs from the general voter population. Norris and Curtice (2008) have found that visiting websites for election information, including official party websites, is significantly positively related to communicating about politics with family and friends. This conclusion led them to assume that the effects of political websites on the population may be indirect, operating through the mechanism of the two-step information flow. Karlsen (2015) compared Norwegian voters who follow politicians or parties on Facebook with the non-follower population. He has demonstrated that the large majority of voters who follow political actors are opinion leaders, 
have larger networks on Facebook and Twitter, and communicate about politics more frequently both online and offline than the non-follower population. Communicating about politics is a prerequisite to exert political influence, and these findings suggest that politicians' digital communication tools reach and inform those voters who are highly active participants of mundane political discussions both offline and on social media platforms. While based on Bimber and Davis's findings, one can argue that politicians' online communication is only 'preaching to the converted' (see Norris, 2003), these subsequent results have raised the possibility of 'preaching through the converted' (see Vissers, 2009). Second, the growing relevance of social media in voters' political information consumption has reinvigorated the idea of social influences on political behavior. Social media as an information resource is strongly shaped by peer communication, while the reach of ordinary citizens' communication has been incredibly extended. Any public political expression (posts, shares, comments or reactions) can be seen by hundreds of others and the information users consume through their news feeds is largely composed of their friends' public utterances. Subsequent research demonstrated the presence and importance of social influences on political participation (Bond et al, 2012), news selection (Messing \&Westwood, 2014), the perceived credibility of news contents (Turcotte et al, 2015), political opinions (Diehl et al, 2016) and political attitudes (Bene, 2017a). In light of these findings, it appears that political actors' messages may exert a stronger influence on voters through ordinary citizens' transmission than it could do directly.

\section{Toward a Performance-Oriented Approach}

As described above, most electoral performance studies have applied an adoptionfocused approach: they have investigated how the use of digital media tools affects candidates' electoral performance. However, the commodification of digital media in election campaigns (see Vaccari, 2010; Bimber, 2014) requires moving beyond this question. When 
using social media for campaigning is fairly common among candidates, the crucial question is not whether its adoption affects their electoral performance, but rather how the way it is used influences electoral success. Recently, some Dutch scholars have applied a more content-focused perspective to explore the effect of website and social media use on electoral performance. They have investigated the effects of interactive features used on websites (van Noort et al, 2016) Twitter (Kruikemeier, 2014), or personalized Twitter use (Kruikemeier, 2014) and the number of tweets posted (Spierings \& Jacobs, 2014; Kruikemeier, 2014; Jacobs \& Spierings, 2016a).

However, the effects of politicians' social media activity on users' reactions may be more important than these activities in themselves. The visibility of these activities strongly depends on the reactions they trigger due to both the nature of virality (see Klinger \& Svensson, 2015) and the power of algorithm (see Bucher, 2012). Highly reacted content can be seen by a much wider circle of users, whereas low reacted content is seen by a much narrower circle of users than the overall number of direct followers. Facebook offers three quantitative indicators of different reactions: numbers of likes, comments and shares. Given the audience-boosting nature of these reaction types, politicians are presumably intent on triggering reactions with their posts, therefore they can be considered unambiguous metrics of Facebook performance. To my knowledge, only two studies have adopted a performanceoriented approach to date. Wagner and Gainus (2009) investigated how the Google PageRank's scores of congressional candidates' websites affected the numbers of votes they gained in the 2006 US midterm election. The PageRank score indicates the level of a particular website's web presence based on its income links; thereby it is basically a Web 1.0 metric of the level of viral performance. They found that this score was positively associated with the number of votes Democratic candidates gained, but in the case of Republican candidates, no significant effect was detected. In the social media context only one recent 
pilot study has used a performance-oriented approach: Effing and his colleagues (2016) have elaborated a social media indicator whose one component measures the aggregated followers' engagement with candidates' activity in different social media platforms. The pilot study conducted in local municipal elections in the Netherlands showed mixed results on the effect of this indicator on the preferential vote, but the sample was rather limited in this work.

\section{Hypotheses of the Research}

Klinger and Svensson (2015) argue that the distribution logic of social media is virality. Content reaches wider segments of users if it is shared by followers. In light of the two-step flow hypothesis, getting viral is the key prerequisite for gaining electoral benefits from using social media. As discussed above, this idea suggests that candidates can serve their electoral interest by 'preaching through the converted' (Vissers, 2009) rather than 'preaching to the converted' (Norris, 2003). The three types of Facebook reactions differ from each other in their viral character. Although in some cases liking and commenting is visible for Facebook friends, admittedly, sharing has the strongest viral potential (see Bene, 2017b). In line with this finding, this study hypothesizes that the higher number of average shares on Facebook results in more personal votes for candidates. Personal vote is the 'portion of candidate's electoral support which originates in his or her personal qualities, qualifications, activities and records' (Cain et al, 1984: 111), and thereby is independent of his or her party affiliation.

\section{H1: The more average shares per post a candidate receives during the election} campaign, the more personal votes (s) he gains in the election.

However, a significant relationship between the number of average shares and vote shares would still not prove that extra votes resulted from the indirect two-step flow effects. First, one can argue that extra votes were due to the direct effects of the followers' experience of involvement and engagement. This assertion corresponds with the 'crystallization' 
hypothesis first proposed by D'Alessio (1997). He suggested that effects of web sites on candidate performance could result from their capacity to persuade visitors who already had a leaning towards the candidate but were uncertain about their participation in voting rather than their ability to induce voters to change their votes. The interactive features Facebook offers may facilitate this 'crystallization'. Studies have shown that expressive actions lead to political participation both offline (Huckfeldt \& Sprague, 1995), and in the social media context (de Zúniga et al, 2015) as they may help clarify one's political views, increase internal political efficacy and strengthen the commitment to the views expressed (de Zúniga et al, 2015: 615, Vaccari et al, 2015: 223). As a result, engaging with political content posted by candidates may help ‘crystallyze' followers' pre-existing political views and get them to vote. Consequently, it is conceivable that extra votes resulting from shares are due to a direct effect on followers who share those posts, rather than an indirect effect on friends who see the shared posts. Secondly, a possible relationship may stem from reverse causality, an explanation which was also propounded by D'Alessio (1997). More popular candidates reap more shares, therefore it is not the high number of shares that results in extra votes; on the contrary, the general popularity reflected in the high number of personal votes leads to the high number of shares.

These alternative causal explanations can be partly tested by the investigation of the effects of other performance variables, namely the number of average likes and comments per post. If engagement with candidates' posts resulted in 'crystallyzing' political views, it could be expected that it has to occur also for liking and, more notably, also for commenting posts. In addition, a general popularity on Facebook can be well captured by the number of comments, and even more notably, by the number of likes candidates trigger with their posts. Based on this argument, if the number of average shares is significantly positively correlated with vote share, while the number of average likes and comments is not, then both the 
'crystallyzing' hypothesis and the reverse causality assumption can be rejected, yielding stronger arguments for an indirect, two-step flow hypothesis.

H2 The average number of likes per post a candidate receives during an election campaign is not significantly associated with personal vote.

$H 3$ The average number of comments per post a candidate receives during election campaign is not significantly associated with personal vote.

\section{The Hungarian Case}

For the 2014 election a new electoral system had been introduced in Hungary. The new law preserves the mixed-member system characterizing Hungarian electoral system after 1989, even if its majoritarian elements have been strengthened. In the new two-tier electoral system, voters have two votes: one for the single-member district (SMD) representative and one for a national party list (for more detail about the new system and the changes, see Ilonszki \& Várnagy, 2016). Previous research on the effects of ICT campaign tools on electoral performance focused on either proportional systems allowing preference vote on the list (e.g. Jacobs \& Spierings, 2016a; Sudulich, 2010) or majoritarian systems (e.g. D’Alessio, 1997; Gibson \& McAllister, 2011, 2015). In the case of preference votes on open or semiopen party lists, personal vote originates from an intra-party competition. In the case of clear majoritarian electoral systems, it is impossible to separate who is the addressee of the votes: the candidate or her party. A crucial benefit of a mixed-member system is that the number of personal votes is easy to assess in inter-party competition (Papp, 2016). Owing to the two votes, there are data about the numbers of votes both for particular parties and for their candidates from each SMD, which makes it possible to determine the numbers of personal votes. At the same time, in a mixed-member system it is more difficult to obtain personal votes than in a proportional electoral system applying open or semi-open party lists, as they have to be gained in inter-party as opposed to intra-party competition: for getting personal 
votes, voters have to share their votes and may support a candidate from a party other than the one they choose on party list. To my knowledge, the effects of ICT campaign tools on personal votes have not been investigated in the mixed-member electoral context.

Further specificities of the Hungarian case are that despite the fact that majoritarian elements are dominant in the electoral system, it is highly party-centred in terms of both candidate selection and electoral rules (see Papp, 2014) and voters usually vote candidates from the parties they supported on the list, thus shared votes are rather unusual (Papp, 2016). Furthermore, Hungary is one of the most partisan biased and polarized countries in Europe (see Patkós, 2017; Enyedi \& Tóka, 2007) and has the smallest electoral volatility among postcommunist countries (Powell \& Tucker, 2014) ${ }^{1}$. According to Jacobs and Spierings (2016a), effects of social media campaigning on electoral performance are expected to be the strongest in contexts where parties are weak and party identification is low, as a setting like that puts a stronger emphasis on candidates who can take advantage of personalized campaign tools like social media. This idea implies that the Hungarian context is a least likely case when it comes to effects of social media on electoral performance: getting personal votes from inter-party competition owing to social media activities in a party-centred system with highly partisan, committed voters seems to be highly unlikely. However, despite the difficulties, SMD candidates in 2014 made efforts to gain personal votes (Papp, 2015), moreover, personal vote seeking is an important aspect when parties select their candidates (Papp \& Zorigt, 2016) and social media may be an important campaign tool in personal vote seeking efforts (Enli \& Skogerbø, 2013; Zittel, 2015).

\footnotetext{
${ }^{1}$ Powell and Tucker's data covered only the period from 1990 to 2006, while the election of 2010 resulted in a substantial transformation of the party system. However, the result of the 2014 election was very similar to that of the 2010 election, and public opinion institutes predict no major change in 2017. This suggests that the 2010 election is rather an exception, a critical election (see Róbert \& Papp, 2012), which brought a one-off transformation of patterns of party support, but did not change the overall trend of low level of electoral volatility.
} 
As discussed above, previous research on effects of social media use on electoral performance has focused on either Twitter or an aggregated measure of web 2.0 campaign tools. To my knowledge, the effects of Facebook use have not been investigated. It is surprising, as a recent study (Lilleker et al, 2015) interviewing campaign managers of 68 parties from 12 European countries found that managers consider Facebook as a much more important campaign tool than Twitter. The aggregate results showed that Facebook was listed as the third most important tool in the overall campaign mix right behind face-to-face contact and television presence; moreover even YouTube and e-mail were assessed as more important than Twitter. The gap in the importance attributed to Facebook and Twitter is even wider in new EU member states (Lilleker et al, 2015). The insignificance of Twitter as a campaign tool in the Hungarian context is well illustrated by recent research that has found that only 14 out of the 386 members of parliaments (MP) had a Twitter account in January 2014 (Merkovity, 2016). Regarding the audience, the Reuters Institute Digital Media Report has shown that while out of the 26 countries examined, Hungary has one of the highest shares of citizens who consume news from Facebook (60\%), it has one of the lowest levels in Twitter news consumption (5\%) (Newman et al, 2016). These facts, therefore, justify why Facebook platforms as opposed to Twitter are investigated in this context.

\section{Method}

To test the hypotheses, a unique database was created. From each SMD, the three most voted-for candidates were selected, but out of them only candidates who had a Facebook page were considered. This selection method made up a sample of 184 candidates from 101 SMDs. The dependent variable is the percentage of votes a particular candidate gained (ranging between $8.64 \%$ and $58.85 \%, \mathrm{M}=33.55 \% ; \mathrm{SD}=11.48 \%)^{2}$. Three Facebook-performance indicators are applied as independent variables: the number of average shares $(M=14.26, \mathrm{SD}$

\footnotetext{
${ }^{2}$ For all variables, descriptive statistics are based on the dataset after removing outliers based on the models and cases with missing data $(\mathrm{N}=164)$.
} 
$=26.90)$, likes $(\mathrm{M}=82.77, \mathrm{SD}=159.06)$ and comments $(\mathrm{M}=3.81, \mathrm{SD}=7.09)$ per post posted during the last two weeks of the campaign. ${ }^{3}$ Given the high level of correlation between the three performance-indicators ${ }^{4}$, their effects were tested in distinct models. The most important control variable is the percentage of votes the candidates' parties gained on list within the candidates' districts, which enables us to capture personal vote in the model. Several individual-level variables were employed to control for factors assumed to have effects on personal votes. Gender $(1=$ male, $90 \%$ males) and age (ranged between 25 and 75, $\mathrm{M}=46.96, \mathrm{SD}=10.95$ ) are candidates' general characteristics, whereas party leader position $(1=\text { leader, } 4 \% \text { leaders })^{5}$, incumbency $\left(1=\right.$ incumbent, $38 \%$ incumbents $^{6}{ }^{6}$, local mayor position $\left(1=\right.$ mayor, $37 \%$ mayors $^{7}$, party affiliation $^{8}$ and the number of elections a given candidate has run in since $2002^{9}$ are factors that may increase candidates' name recognition in their districts. This data was obtained from public sources. Presence in professional media can also increase name recognition and help spreading candidates' campaign messages. Of the great number of media channels, the two leading broadsheets, the left-leaning Népszabadság and the right-leaning Magyar Nemzet were selected. The numbers of mentions of candidates' names during the last two weeks of the campaign were coded and summed into a media presence variable (ranging between 0 and $13, \mathrm{M}=0.90, \mathrm{SD}=1.93$ ). Apparently, the two leading broadsheets alone do not fully represent candidates' media presence, but it can be

\footnotetext{
${ }^{3}$ Posted from 23rd March 2014 to 6th April 2014. However, the data were collected later, between January and July 2015, therefore there may be some distortion due to deleted profiles and posts.

${ }^{4}$ The score of Pearson's $R$ between average numbers of shares and likes is 0.85 , between average numbers of shares and comments is 0.39 and between average numbers of likes and comments 0.52 .

${ }^{5} \mathrm{~A}$ particular candidate was coded as party leaders if (s)he had a party position as president, vice-president or leader of parliamentary group. (Dummy variable)

${ }^{6}$ The number and magnitude of SMDs was significantly changed from 2010 to 2014, therefore understanding incumbency is somewhat difficult. Those candidates were considered incumbent who gained SMD mandates in 2010 from any part of the newly formed districts. (Dummy variable)

${ }^{7}$ Those candidates were coded as local mayors who hold this position in any settlement of the districts at the moment of the election. (Dummy variable)

${ }^{8}$ Only Fidesz-KDNP (right-wing government party union, $\mathrm{N}=74$ ), Kormányváltás (oppositional coalition of left-wing parties, $\mathrm{N}=55$ ) and Jobbik (radical right oppositional party, $\mathrm{N}=35$ ) candidates are included in the dataset. All the four $L M P$ (green, antiestablishment party) candidates included in the original sample were outliers. Independent or other party candidates could get into the three most voted-for candidates in none of the SMDs.

${ }_{9} 3$ elections $=29$ candidates, 2 elections $=27$ candidates, 1 election $=45$ candidates, 0 election $=63$ candidates
} 
considered as a proxy. Finally, Jacobs and Spierings (2016a) show that the number of posts candidates posted can also have an effect on electoral performance, thus it was also controlled for (ranging between 1 and 157, $\mathrm{M}=37.98, \mathrm{SD}=25.15)^{10}$.

\section{Findings}

The results of linear regression models are seen in Table 1 . The variance of the dependent variable is explained by the extraordinarily large extent of models, although this is mainly due to the list vote variable: the vote shares of candidates are highly consistent with the vote shares of their parties. This result is not surprising in a party-centric political context. However, the small unexplained variance shows that some personal votes do still exist and including the other candidate-level variables significantly improves the models' explanatory power $(\mathrm{F}(11,151)=2.62, \mathrm{p}<0.01)$.

Results show that the left-liberal oppositional candidates gain significantly more personal votes than Fidesz-KDNP candidates in each model, which is probably due to some newly formed parties that used highly deceptive names and thus confused some voters. ${ }^{11}$ Gender is significant in the first model: female candidates gained significantly more personal votes than their male counterparts. Even if gender is only a control variable in this research, it is an interesting finding in the Hungarian context. Of the 10 post-socialist, EU- countries in CEE, the Hungarian parliaments have the lowest share of female representatives (Montgomery \& Ilonszki, 2016: 701). Previous results showed that party selection plays an important role in female underrepresentation (Tóth \& Ilonszki, 2015). Interestingly, it is the SMD candidacy where females are the most underrepresented (see Montgomery \& Ilonszki, 2016: 721) a fact which suggests that parties may believe that voters are less likely to directly vote for women than men. However, research shows that Hungarian voters' attitudes toward

\footnotetext{
${ }^{10}$ Posted between 23rd March and 6th April 2014

${ }^{11}$ While the former election system applied strict conditions to have a party list, the new election system made it much easier to have one. Owing to this change, some formerly nonexistent parties appeared right before the election, and some of them used names which were closely tied to the left-liberal oppositonal parties (see Ilonszki \& Várnagy, 2016).
} 
female representation in a comparative perspective is not at all negative (Montgomery \& Ilonszki, 2016: 712), moreover, no significant relationship between gender and personal vote was found in the elections between 1998 and 2010 (Tóth \& Ilonszki, 2015). However, this result is another leap forward, as the first model shows that women received even more personal votes than men. Although the relationship is not significant in the second and third models, all they show that nomination of women in SMDs do not jeopardize electoral success, consequently parties' reluctance to select female candidates in SMDs is not justifiable from an electoral success perspective.

Regarding independent variables, the results show that all hypotheses are supported. The more average number of shares one gets on Facebook, the more personal votes she gains in elections. Even though the effect size is quite small, it is significant: one share increase in the average number of shares results in $0.006 \%$ extra votes. Considering that 76000 voters were in one district on average $\mathrm{e}^{12}$ and the voter turnout was $61.24 \%$, one share increase means approximately 2.8 extra votes. Admittedly, this gain seems to be fairly moderate, but there are remarkable differences in the numbers of average shares between the candidates and larger variances can result in considerable numbers of extra votes, which may be decisive in a more competitive SMD. The second and third models indicate that it is not a general Facebook popularity or crystallization effect that results in personal votes: the number of average likes and comments is not significantly related to the vote share candidates gain. These results suggest that the extra-votes can be gained from those voters who see the politicians' content mediated by their Facebook friends rather than the followers who engage with the posts. It is important that the other candidate-level variables did not account for personal vote, thus Facebook performance seems to be more important in gaining personal votes than factors like age, incumbency, number of elections candidates run in, local mayor or party leader position

\footnotetext{
${ }^{12}$ Századvég Alapítvány: Az új magyar választási rendszer. (The new Hungarian electoral system) http://www.szazadveg.hu/uploads/media/57e923c55360d/az-uj-magyar-valasztasi-rendszerszazadvegtanulmany130802.pdf
} 
or media presence. The number of posts is not significantly associated with vote share either, a result which contradicts Jacobs and Spierings' (2016a) findings from a Dutch context.

Table 1. Linear regression model of candidates' vote shares.

\begin{tabular}{|c|c|c|c|}
\hline & model 1 & model 2 & model 3 \\
\hline Average No of shares & $.006(.003)^{*}$ & & \\
\hline Average No of likes & & $.001(.001)$ & \\
\hline Average No of comments & & & $.012(.008)$ \\
\hline No of posts & $.003(.003)$ & $.004(.003)$ & $.004(.003)$ \\
\hline Gender & $-.519(.244)^{*}$ & $-.462(.259)$ & $-.502(.265)$ \\
\hline Age & $.003(.007)$ & $.002(.008)$ & $.000(.008)$ \\
\hline Local mayor & $.046(.153)$ & $.020(.151)$ & $-.001(.155)$ \\
\hline Party leader & $-.091(.385)$ & $-.232(.388)$ & $-.108(.403)$ \\
\hline Incumbency & $.259(.361)$ & $.256(.362)$ & $.240(.354)$ \\
\hline No of elections & $-.005(.081)$ & $.015(.081)$ & $.008(.084)$ \\
\hline Party_Kormányváltás ${ }^{1}$ & $.931(.434)^{*}$ & $.995(.412)^{*}$ & $.991(.409)^{*}$ \\
\hline Party_Jobbik ${ }^{1}$ & $.329(.502)$ & $.444(.4878)$ & $.436(.479)$ \\
\hline media presence & $.038(.039)$ & $.028(.037)$ & $.052(.042)$ \\
\hline List votes & $1.030(.014)^{* * *}$ & $1.029(.014)^{* * *}$ & $1.030(.014)^{* * *}$ \\
\hline Constant & $-1.070(.811)$ & $-1.093(.894)$ & $-.961(.896)$ \\
\hline Adjusted $\mathrm{R}^{2}$ & .993 & .992 & .992 \\
\hline $\mathrm{N}^{2}$ & 164 & 164 & 164 \\
\hline
\end{tabular}

Note: Values in each cell are b values and standard errors are in parentheses. Standard errors clustered on SMDs. ${ }^{*} \mathrm{p}<.05, * * \mathrm{p}<.01, * * * \mathrm{p}<.001 .^{1}$ the reference category is FideszKDNP. ${ }^{2}$ After removing outliers and cases with missing data.

\section{Conclusion}


The study has investigated how Facebook-performance affects electoral performance in a context which is considered a least likely case due to the high level of partisan bias, partycentred political system and low level of volatility. To date, this study is the first to investigate the effects of social media use on electoral outcome in a mixed-member electoral system where personal votes can be the most precisely assessed. Furthermore, this is one of the first research projects to focus on the effects of social media performance rather than its adoption, and the first to deal with Facebook-campaigning rather than Twitter or some aggregated social media use.

Results show that the number of average shares of candidates' Facebook posts during the last two weeks of the Hungarian general election campaign of 2014 has a modest but significant positive effect on personal votes. At the same time, the other Facebook performance indicators, i.e. the numbers of average likes and comments, are not significantly associated with electoral outcome. These findings suggest that a social media campaign can result in extra votes through a two-step flow effect: the extra votes are likely to come from voters who get candidates' messages mediated by their friends and who otherwise would not see the given content. The two-step flow explanation as a causal mechanism of the effects of ICT campaign tools on electoral performance was also hypothesized by previous research, but to date no empirical evidence has existed supporting this thesis.

The modest size of the effect entails that Facebook-performance can be an electiondecisive factor in the case of a highly competitive electoral race when there are remarkable differences in the candidates' Facebook performance. Consequently, Facebook is not a silver bullet for electoral success; one cannot expect a great amount of extra personal votes from a successful Facebook-campaign. However, the significant effect in a highly partisan context with low electoral volatility indicates that stronger effects may exist in a less partisan, more candidate-centred political system, which should be investigated by future studies. Moreover, 
it is important to note that personal vote is a fairly strict criterion when examining the effects of social media use on electoral success. It is conceivable that candidates' Facebook campaigns result in extra votes not only for the candidates, but also for their respective parties. However, a research design focusing on personal vote cannot detect these extra votes. Future studies controlling for party support data in SDMs preceding the campaign rather than party vote share on list could identify these effects. Finally, it is important that the number of average shares is one of the most important predictors of personal votes within the model, while most control variables, including age, incumbency, number of elections candidates run, local mayor or party leader position, media presence or number of posts posted during the campaign have no significant effect on electoral outcome.

Naturally, the research has some limitations. It has little data about offline campaigning; only the presence in two national broadsheets could be controlled for, there were no available data about campaign spending, number of offline meetings and events organized by candidates or presence in local media. Also, some candidates, posts or shares, comments and likes may have disappeared due to pages and posts deleted by the time data were collected.

Nonetheless, the study has highlighted the importance of Facebook-performance, and future studies should examine this aspect in other contexts as well. A comparative research design would also be an important further step. Moreover, two-step flow effects should be more deeply addressed to examine how politicians' shared posts influence voters' political behavior.

\section{References}

Bene, M. (2017a). Influenced by Peers. Facebook as an Information Source for Young People. Social Media + Society, Forthcoming. 
Bene, M. (2017b). Go viral on the Facebook! Interactions between candidates and followers on Facebook during the Hungarian general election campaign of 2014. Information, Communication \& Society, 20(4), 513-529.

Bimber, B. (2014). Digital media in the Obama campaigns of 2008 and 2012: Adaptation to the personalized political communication environment. Journal of Information Technology \& Politics, 11(2), 130-150.

Bimber, B., \& Davis, R. (2003). Campaigning online: The Internet in US elections. Oxford University Press.

Bond, R. M., Fariss, C. J., Jones, J. J., Kramer, A. D., Marlow, C., Settle, J. E., \& Fowler, J. H. (2012). A 61-million-person experiment in social influence and political mobilization. Nature, 489, 295-298.

Bucher, T. (2012). Want to be on the top? Algorithmic power and the threat of invisibility on Facebook. New Media \& Society, 14(7), 1164-1180.

Cain, B. E., Ferejohn, J. A., \& Fiorina, M. P. (1984). The constituency service basis of the personal vote for US representatives and British members of parliament. American Political Science Review, 78(01), 110-125.

D'alessio, D. (1997). Use of the World Wide Web in the 1996 US election. Electoral Studies, 16(4), 489-500.

Diehl, T., Weeks, B. E., \& de Zúñiga, H. G. (2016). Political persuasion on social media: Tracing direct and indirect effects of news use and social interaction. New Media \& Society, 18(9), $1875-1895$.

Effing, R., van Hillegersberg, J., \& Huibers, T. (2016). Social media indicator and local elections in The Netherlands: towards a framework for evaluating the influence of Twitter, YouTube, and Facebook. In Sobaci, M. Z. (Ed.) Social Media and Local Governments (pp. 281-298). Springer International Publishing. 
Enli, G. S., \& Skogerbø, E. (2013). Personalized campaigns in party-centred politics: Twitter and Facebook as arenas for political communication. Information, Communication \& Society, 16(5), 757-774.

Enyedi Zs. \& Tóka, G. (2007). The Only Game in Town: Party Politics in Hungary. In Webb, P. \& White, S. (eds.) Party Politics in New Democracies. Oxford University Press.

Gibson, R. (2012). From brochureware to 'MyBo': An overview of online elections and campaigning. Politics, 32(2), 77-84.

Gibson, R. K., \& McAllister, I. (2006). Does cyber-campaigning win votes? Online communication in the 2004 Australian election. Journal of Elections, Public Opinion and Parties, 16(3), 243-263.

Gibson, R. K., \& McAllister, I. (2011). Do online election campaigns win votes? The 2007 Australian "YouTube" election. Political Communication, 28(2), 227-244.

Gibson, R. K., \& McAllister, I. (2015). Normalising or equalising party competition? Assessing the impact of the web on election campaigning. Political Studies, 63(3), 529-547. Gil de Zúñiga, H., Molyneux, L., \& Zheng, P. (2014). Social media, political expression, and political participation: Panel analysis of lagged and concurrent relationships. Journal of Communication, 64(4), 612-634.

Huckfeldt, R. R., \& Sprague, J. (1995). Citizens, politics and social communication: Information and influence in an election campaign. Cambridge University Press. Ilonszki, G., \& Várnagy, R. (2016). Parliamentary elections in Hungary, 2014. Electoral Studies, (43), 169-172.

Jacobs, K., \& Spierings, N. (2016a). Saturation or maturation? The diffusion of Twitter and its impact on preference voting in the Dutch general elections of 2010 and 2012. Journal of Information Technology \& Politics, 13(1), 1-21. 
Jacobs, K., \& Spierings, N. (2016b). Social media, parties, and political inequalities.

Springer.

Karlsen, R. (2015). Followers are opinion leaders: The role of people in the flow of political communication on and beyond social networking sites. European Journal of Communication, 30(3), 301-318.

Klinger, U. \& Svensson, J. (2015). The emergence of network media logic in political communication: A theoretical approach. New Media \& Society,17(8), 1241-1257.

Koc-Michalska, K., Lilleker, D. G., Surowiec, P., \& Baranowski, P. (2014). Poland's 2011 online election campaign: New tools, new professionalism, new ways to win votes. Journal of Information Technology \& Politics, 11(2), 186-205.

Kruikemeier, S. (2014). How political candidates use Twitter and the impact on votes. Computers in Human Behavior, 34, 131-139.

Lazarsfeld, P., Berelson, B., \& Gaudet, H. (1948). The people's choice. New York: Columbia University Press.

Lilleker, D. G., Tenscher, J., \& Štětka, V. (2015). Towards hypermedia campaigning? Perceptions of new media's importance for campaigning by party strategists in comparative perspective. Information, Communication \& Society, 18(7), 747-765.

Merkovity, N. (2016). Az önmediatizáció jelensége az online politikai kommunikációban. [The Phenomenon of Self-Mediatisation in the Online Political Communication.] Politikatudományi Szemle, 25(2), 111-132.

Messing, S., \& Westwood, S. J. (2014). Selective exposure in the age of social media: Endorsements trump partisan source affiliation when selecting news online. Communication Research, 41(8), 1042-1063. 
Montgomery, K. A., \& Ilonszki, G. (2016). Stuck in the Basement: A Pathway Case Analysis of Female Recruitment in Hungary's 2010 National Assembly Elections. Politics \& Gender, 12(4), 700-726.

Newman, N., Fletcher, R., Levy, D. A. L., \& Nielsen, R. K. (2016). Reuters Institute Digital News Report 2016. Reuters Institute for the Study of Journalism.

Norris, P. (2003). Preaching to the converted? Pluralism, participation and party websites. Party Politics, 9(1), 21-45.

Norris, P., \& Curtice, J. (2008). Getting the message out: A two-step model of the role of the Internet in campaign communication flows during the 2005 British general election. Journal of Information Technology \& Politics, 4(4), 3-13.

Papp, Zs. (2014). Legislators' constituency orientation under party-centred electoral rules: evidence from Hungary. Doctoral Dissertation. Corvinus University of Budapest Papp, Zs. (2015). Campaign-Personalization and Constituency Focus in a Mixed-Member Electoral System. The Case of Hungary. World Political Science, 11(1), 75-95.

Papp, Zs. (2016). Inkumbens-hátrány, helyi kötődés és a személynek szóló szavazat Magyarországon [Disadvantage of Incumbents, Local Linkages and Person-Motivated Vote in Hungary]. Politikatudományi Szemle, 25(2), 31-56.

Papp, Zs., \& Zorigt, B. (2016). Party-directed personalisation: the role of candidate selection in campaign personalisation in Hungary. East European Politics, 32(4), 466-486.

Park, H. M., \& Perry, J. L. (2008). Do campaign web sites really matter in electoral civic engagement? Empirical evidence from the 2004 post-election internet tracking survey. Social Science Computer Review, 26(2), 190-212.

Patkós, V. (2017). A pártos polarizáció okai és hatásai az európai demokráciákban [Causes and effects of partisan polarisation in European democracies]. Doctoral dissertation. Corvinus University of Budapest. 
Powell, E. N., \& Tucker, J. A. (2014). Revisiting electoral volatility in post-communist countries: New data, new results and new approaches. British Journal of Political Science, 44(1), 123-147.

Rackaway, C. (2007). Trickle-down technology? The use of computing and network technology in state legislative campaigns. Social Science Computer Review, 25(4), 466-483. Róbert, P. \& Papp, Zs. (2012). Kritikus választás? Pártos elkötelezettség és szavazói viselkedés a 2010-es országgyülési választáson [Critical Election? Partisan Commitment and Voting Behavior during the Hungarian General Election of 2010.] In Boda, Zs. \& Körösényi, A. (Eds.) Van irány? Trendek a magyar politikában. Új Mandátum Könyvkiadó.

Sobaci, M. Z., Eryiğit, K. Y., \& Hatipoğlu, İ. (2016). The Net Effect of Social Media on Election Results: The Case of Twitter in 2014 Turkish Local Elections. In Sobaci, M. Z. (ed,) Social Media and Local Governments (pp. 265-279). Springer International Publishing. Spierings, N., \& Jacobs, K. (2014). Getting personal? The impact of social media on preferential voting. Political Behavior, 36(1), 215-234.

Sudulich, M. L., \& Wall, M. (2010). "Every little helps”: Cyber-campaigning in the 2007 Irish general election. Journal of Information Technology \& Politics, 7(4), 340-355. Tóth, A. \& Ilonszki, G. (2015). Pártok vagy választók? A női jelöltek esélye az egyéni válaszókerületekben, 1998-2010. [Parties or Voters? The Opportunity Structures of Female Candidates in Single Member Districts 1998-2010.] Politikatudományi Szemle, 24(3), 27-51. Turcotte, J., York, C., Irving, J., Scholl, R. M., \& Pingree, R. J. (2015). News recommendations from social media opinion leaders: effects on media trust and information seeking. Journal of Computer-Mediated Communication, 20(5), 520-535. Vaccari, C. (2010). "Technology is a commodity": the internet in the 2008 United States presidential election. Journal of Information Technology \& Politics, 7(4), 318-339. 
Vaccari, C., Valeriani, A., Barberá, P., Bonneau, R., Jost, J. T., Nagler, J., \& Tucker, J. A. (2015). Political Expression and Action on Social Media: Exploring the Relationship Between Lower-and Higher-Threshold Political Activities Among Twitter Users in Italy. Journal of Computer-Mediated Communication, 20(2), 221-239.

van Noort, G., Vliegenthart, R., \& Kruikemeier, S. (2016). Return on interactivity? The characteristics and effectiveness of Web sites during the 2010 Dutch local elections. Journal of Information Technology \& Politics, 13(4), 352-364.

Vissers, S. (2009). From Preaching to the Converted to Preaching through the Converted. Paper presented to ECPR Joint Research Workshops. Lisbon. 14-19 April.

Wagner, K. M., \& Gainous, J. (2009). Electronic grassroots: Does online campaigning work?. The Journal of Legislative Studies, 15(4), 502-520.

Zittel, T. (2015). Do Candidates Seek Personal Votes on the Internet? Constituency Candidates in the 2009 German Federal Elections. German Politics, 24(4), 435-450. 